\title{
Selection Criteria and Performance of Energycane Clones (Saccharum spp. $\times$ S. spontaneum) for Biomass Production Under Tropical and Sub-tropical Conditions
}

\author{
Ramón G. León ${ }^{1}$, Robert A. Gilbert ${ }^{2}$, Pedro H. Korndorfer ${ }^{3}$ and Jack C. Comstock ${ }^{4}$
}

\begin{abstract}
The urgent need to reduce our reliance on oil and at the same time reduce carbon emissions, has triggered the search for alternative energy sources such as biofuels. New technologies have made possible the conversion of cellulose and hemicellulose into sugars that can be fermented to produce ethanol. This opened the possibility that any plant species can be used for ethanol production. Species that produce large amounts of biomass in a short time are desirable. For this reason, one of the most critical steps in the development of biofuel production is to identify appropriate species that will provide the necessary biomass for cellulosic ethanol or direct combustion. Energycanes are wide crosses of commercial sugarcane (a complex hybrid of Saccharum spp.) with $S$. spontaneum clones which produce high-biomass plants with high fiber content and good cold and disease tolerance as well as excellent ratooning ability. A large scale study has been established to evaluate biomass production, growth characteristics and invasive potential of energycane clones under tropical (Limón, Costa Rica) and subtropical (South Florida) conditions since 2008. In Florida in a low fertility sandy soil, energycane clones and the grass species Pennisetum purpureum var. Merkeron showed the highest yields ranging from 50 to 78 ton ha ${ }^{-1}$ of fresh weight. These clones were not susceptible to smut (Sporisorium scitaminea) unlike the energycane L79-1002 which is currently the most widely grown clone of energycane. Most clones showed lateral vegetative growth, but no pollen or seed viability. In Costa Rica, the evaluation of 15 energycane clones is still in progress, however preliminary results indicated that the energycane clones had faster and more vigorous growth than the commercial sugarcane varieties, only exceeded by $P$. purpureum. In comparison with commercial sugarcane varieties, the energycane clones recorded $37 \%$ higher leaf area index (LAI) and height, and 65\% more stalks per unit area. No evident disease susceptibility was observed in the energycane clones in the tropics, although lateral vegetative growth was observed in all clones. Additionally, all clones flowered and produced viable pollen which suggests that these clones have a higher invasive potential in the tropics. The information available until now suggests that the behavior of energycane germplasm varies importantly between tropical and sub-tropical conditions. Therefore, selection and breeding programs must be carefully developed accounting for the unique responses that this germplasm could show under these two different climatic conditions.
\end{abstract}

Key words: Biomass, biofuel, invasiveness, feedstock.

\section{Criterios de selección y desempeño de clones de caña energética (Saccharum spp. $\times$ S. spontaneum) para la producción de biomasa en condiciones tropicales y subtropicales}

Resumen. La necesidad urgente de reducir nuestra dependencia del petróleo y al mismo tiempo reducir las emisiones de carbono ha promovido la búsqueda de fuentes alternativas de energía tales como los biocombustibles. Nuevas tecnologías han hecho posible la conversión de celulosa y hemicelulosa a azúcares que pueden ser fermentadas para producir etanol. Esto abrió la posibilidad de que cualquier especie vegetal pueda ser usada para la producción de este biocombustible. Especies que produzcan grandes cantidades de biomasa en poco tiempo son deseables. Por esta razón, uno de los pasos más críticos en el desarrollo de la producción de biocombustibles es la identificación de las especies adecuadas que proveerán la biomasa necesaria para la producción del etanol celulósico o para combustión directa. Las cañas energéticas son clones de cruces amplios entre la caña de azúcar comercial (complejo de híbridos de Saccharum spp.) con S. spontaneum, los cuales producen plantas con alta biomasa, alto contenido de fibra y buena tolerancia al frío y a enfermedades, además de excelente capacidad

\footnotetext{
${ }^{1}$ Professor, EARTH University, Guácimo, Costa Rica (rleon@earth.ac.cr).

${ }^{2}$ Professor, Everglades Research and Education Center, University of Florida, Belle Glade, FL, USA (ragilber@ufl.edu).

${ }^{3}$ Graduate Research Assistant, Everglades Research and Education Center, University of Florida, Belle Glade, FL, USA (phk@ufl.edu).

${ }^{4}$ Research Plant Pathologist, Sugarcane Field Station, USDA-ARS, Canal Point, FL, USA (Jack.comstock@ars.usda.gov).
} 
de rebrote. Estudios a gran escala han sido establecidos para evaluar la producción de biomasa, las caracterísiticas de crecimiento y el potencial invasivo de clones de caña energética bajo condiciones tropicales (Limón, Costa Rica) y subtropicales (sur de Florida, Estados Unidos de América) desde el 2008. En Florida, en suelos arenosos con baja fertilidad, los clones de caña energética y la especie gramínea Pennisetum purpureum var. Merkeron mostraron los rendimientos más altos con un rango de 50 a 78 toneladas por hectárea de peso fresco. Estos clones no fueron susceptibles al carbón (Sporisorium scitaminea) a diferencia del clon L79-1002, el cual es el clon de caña energética más ampliamente producido actualmente. La mayoría de los clones mostraron crecimiento vegetativo lateral, pero no produjeron polen ni semillas viables. En Costa Rica, la evaluación de 15 clones de caña energética está todavía en proceso, sin embargo, resultados preliminares indicaron que los clones de caña energética tuvieron un crecimiento más rápido y vigoroso que las variedades comerciales de caña de azúcar, solamente superados por el P. purpureum. En comparación con las variedades comerciales de caña de azúcar, los clones de caña energética presentaron un índice de área foliar y altura $37 \%$ superior, y $65 \%$ más de tallos por unidad de área. No se observó susceptibilidad a enfermedades, aunque el crecimiento vegetativo lateral fue detectado en todos los clones, al igual que la producción de inflorescencias y polen viable, lo que sugiere que estos clones tienen un potencial invasivo mayor en el trópico. La información disponible hasta el momento, indica que el comportamiento del germoplasma de caña energética varía en forma importante entre las condiciones tropicales y subtropicales. De esta manera, los programas de selección y mejoramiento genético deben ser desarrollados cuidadosamente tomando en cuenta las respuestas únicas que este germoplasma podría mostrar bajo estas dos condiciones climáticas diferentes.

Palabras clave: Biocombustible, Biomasa.

\section{Introduction}

The increased demand for clean energy sources that are renewable and reduce or limit carbon emissions to the atmosphere have favored the development of technologies that allow the transformation of biomass to liquid fuels (Hill et al. 2009). These technologies take advantage of the fact that plants capture solar energy and use it to fix carbon dioxide from the atmosphere and store it in different forms of carbohydrates, being cellulose and hemicellulose predominant forms that are part of the cell walls (Gomez et al. 2008, Ohlrogge et al. 2009).

Traditionally, biomass had been used to generate energy as heat through direct combustion of materials such as firewood or charcoal. However, these forms of energy are not appropriate for the needs of the predominant transportation technologies which rely on liquid fuels such as gasoline and diesel (Ohlrogge et al. 2009). With the intention to reduce the demand for oil derived fuels; several countries have promoted the use of mixtures of ethanol with gasoline (Morgan et al. 2010). Under this new scenario, it has become evident that the traditional sources of ethanol (e.g. sugarcane, corn and sweet sorghum) are not enough to fulfill the global demand for this biofuel.

During the last few years, there have been important advances in technologies that made possible to depolymerize cellulose and hemicellulose molecules into sugars that can be fermented to produce ethanol (Gomez et al. 2008). In other words, this new technology made possible to take any plant residue that have those two compounds and utilize them to produce biofuels. Today, the challenge is to find germplasm that can be used as feedstock and that have desirable characteristics such as those proposed by Long (2008): high dry matter yield, positive net energy balance, low moisture concentration, low lignin content, and low sucrose. All these characteristics favor the efficiency of cellulose conversion, ethanol production and energy use.

Among the species that have been proposed as potential feedstock for cellulosic ethanol production, Miscanthus $\times$ giganteus, switchgrass (Panicum virgatum $\mathrm{L}$.), corn stover, and sugarcane baggasse are the most frequently cited (Burner et al. 2009, Gomez et al. 2008, Heaton et al. 2008, Hill et al. 2009). The first three are the preferred feedstocks for temperate regions and the last one for tropical and subtropical regions.

As part of the breeding programs of USDA-ARS Sugarcane Field Station at Canal Point, Florida, USA, inter-specific crosses between conventional sugarcane (Saccharum spp.) and other species such as Saccharum spontaneum L. are conducted with the goal of moving desirable traits such as ratooning ability, growth vigor, 
cold tolerance and disease resistance from the wild relative to the breeding lines of conventional sugarcane (Wang et al. 2008). Many of the resulting hybrids showed characteristics unwanted in the sugarcane industry such as a vigorous vegetative growth characterized by profuse production of thin and tall stalks, but with low sucrose production and accumulation (Figure 1). However, these characteristics, favor high biomass production making these hybrids potential feedstocks for cellulosic ethanol production and consequently a new energy source. For this reason, they were called "energycane". Studies are being conducted to compare crop growth, biomass yield and fiber concentration of several grass species including enerycane hybrids, and to identify traits and criteria that can be used to develop effective energycane breeding and selection programs.

\section{Energycane in sub-tropical conditions}

There are concerns that planting biofuel crops on land that is traditionally used for food crops might reduce food supply and increase food prices. Therefore, one of the main considerations to identify new biofuel feedstocks is that these materials can be grown in marginal land that is not commonly used for food production (Morgan et al. 2010, Tilman et al. 2009). Therefore, the biofuel crop could diversify the agriculture and help increase the productivity of a given area rather than displace its traditional crops. This is the case in South Florida, where most of the sugarcane production for sucrose is planted in very rich soils (muck soils). However, this sugarcane area is surrounded by sandy soils with low fertility in which sugarcane productivity is low and production costs are higher than in muck soils. Taking this into consideration, energycane evaluations are currently being done in sandy soils to identify germplasm with high biomass yields under this limiting condition. Among the preliminary results of these studies, it must be highlighted that several energycane clones and the grass species $P$. purpureum var. Merkeron showed the highest yields in sandy soils ranging from 50 to 78 ton $\mathrm{ha}^{-1}$ of fresh weight (Figure 2). Other grass species that had been reported as high yielding such as Miscanthus $\times$ giganteus in temperate regions (Heaton et al. 2008) and Arundo donax in temperate, sub-tropical and
Mediterranean conditions (Mack 2008, Matineo et al. 2009), showed very poor growth and yield. During the growing season, differences in leaf area index (LAI) and stalk number per unit area reflected the differences that were later observed in fresh weight production. Therefore, these two indicators could be useful for germplasm selection programs.

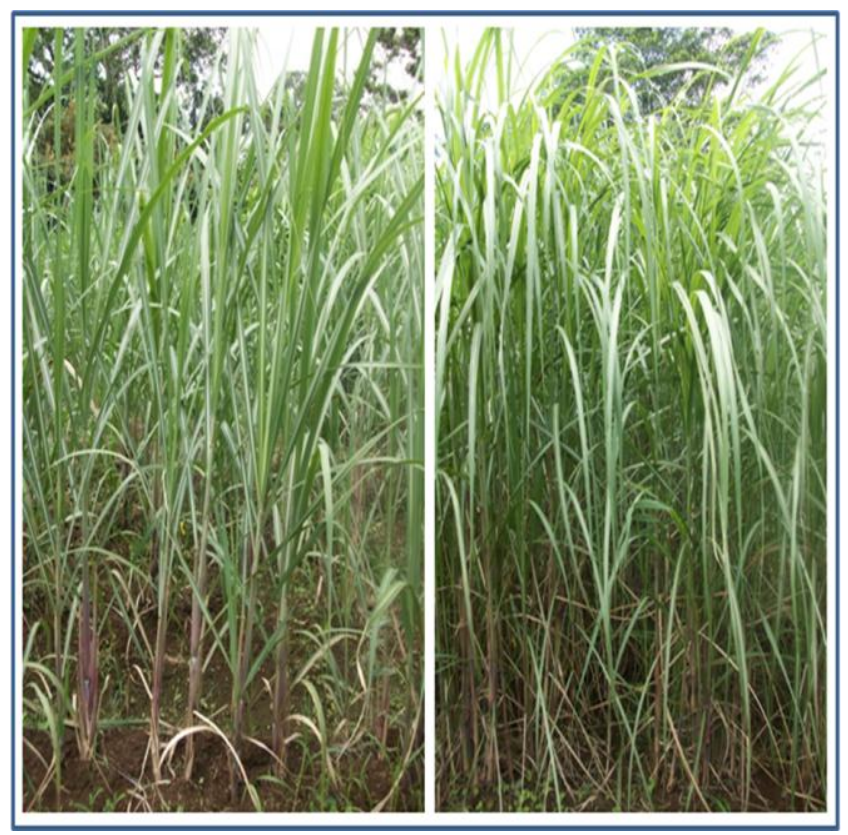

Figure 1. Phenotypical differences in stalk number, height, thickness and in leaf number and area between a commercial sugarcane var. Pindar (left) and an energycane clone US 88-1006 (right).

The energycane clones showed abundant stalk production, lateral vegetative growth which could make difficult the implementation of agricultural practices that require a well defined row. Overall, the clones showed a vigorous growth in the first ratoon. Sugarcane can be very susceptible to smut disease, which can significantly reduce biomass production. Thus, smut resistance must be part of the selection criteria. For example, the energycane clone L79-1002 showed higher number of stools and whips in comparison with other energycane clones that demonstrated high levels of resistance to the disease. 


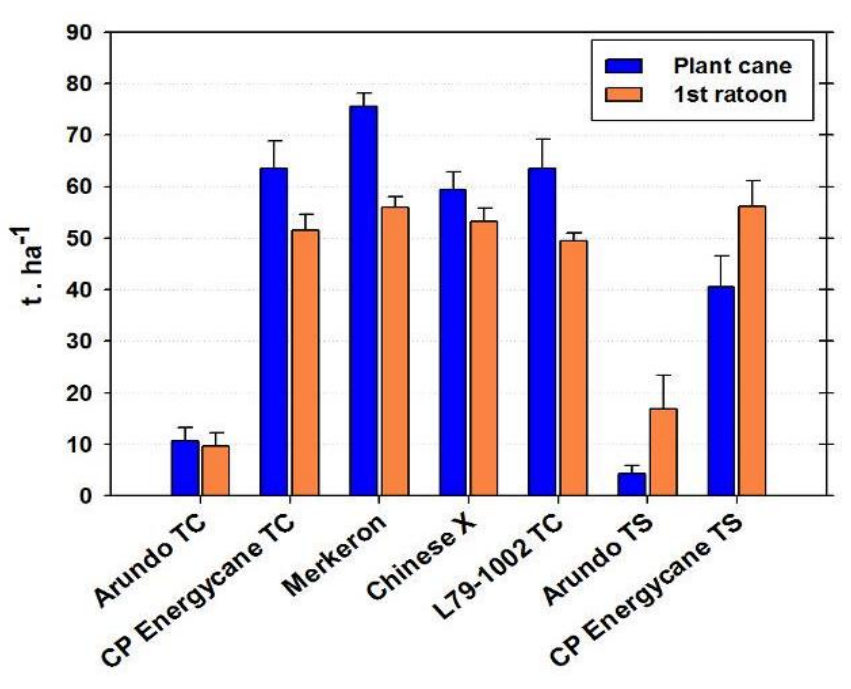

Figure 2. Fresh weight production of Arundo, energycane clones from Canal Point, FL, two Pennisetum varieties (Merkeron and Chinese X) and an energycane clone from Louisiana (L79-1002) grown in sandy soils conditions in Tecan (TC) and Townsite (TS), FL in 2008 (Plant cane) and $2009\left(1^{\text {st }}\right.$ ratoon).

Fiber quality is an important characteristic especially for cellulosic ethanol production. There are almost no differences in cellulose and hemicellulose content that was approximately 40 and $30 \%$, respectively, for not only energycane clones, but also for other grass species. However, it is worth noting that $P$. purpureum and A. donax (9.6\%) showed higher levels of lignin (9.2 to $11.6 \%$ and $9.6 \%$, respectively) compared to the energycane clones (6.5 to $7.9 \%$ ). High levels of lignin in the fiber can reduce the efficiency of the cellulose to ethanol conversion process (Gomez et al. 2008).

\section{Energycane in tropical conditions}

Although most of the current research and technology development for cellulosic ethanol production is taking place in temperate and subtropical regions, the potential for biomass production under tropical conditions is high. This is due to the fact that temperatures are favorable for plant growth year round, and in the humid tropics, water supply is also fairly steady. For this reason the tropics could become an important source of biomass for biofuel production. An energycane germplasm study for the tropics was established in Limón, Costa Rica in 2009. In this case, the goal was also to identify germplasm that can grow in marginal tropical soils that are characterized by high clay content, low soil $\mathrm{pH}$ and high iron and aluminum content. Preliminary results indicated that as it was observed in Florida, energycane clones and $P$. purpureum had the highest potential for biomass production (Figure 3). In this case too, LAI and stalk number per area were good indicators of growth potential. In comparison with commercial sugarcane varieties, the energycane clones recorded $37 \%$ higher leaf area index (LAI) and 65\% more stalks per unit area. Stalk height was also superior in the energycane compared to the commercial varieties, but there were no major differences in this parameter across clones. At the time this work was presented in the International Conference on Bio-fuel Crop Production and Development 2010, this experiment had not reached harvest time. However, a preliminary biomass sub-sampling was conducted based on a limited number of representative stalks. This sub-sampling proved to be misleading due to high variability in stalk number per area across clones, so it is difficult to obtain accurate biomass production measurements using this approach. Thus, final harvest of representative areas that contain a relatively large number of stalks is a more recommendable approach.

All the energycane clones showed lateral vegetative growth (Figure 4). In some cases, a stalk was produced more than $50 \mathrm{~cm}$ away from the planting row. However, this type of behavior represented less than $0.6 \%$ of the stalks. No germplasm showed smut disease although one clone US84-1002 was highly susceptible to mites losing at least two thirds of its leaf area due to their attack.

A major difference observed between the Florida and Costa Rica's studies that indicated a strong Genotype $\times$ Environment interaction was that few of the energycane clones flowered in Florida, while practically all the clones flowered between 9 and 11 months after planting in Costa Rica. There was high variability in inflorescence density, where clones such as US 84-1014 and US 84-1017 produced more than 
five inflorescences per square meter, while others such as 875-3, US 88-1002 and US 88-1006 produced less than 0.1 inflorescences per square meter, indicating that there is potential to develop breeding strategies to select against flowering. Preliminary tests showed pollen viability ranging from 30 to $64 \%$, but most of the clones showed similar levels. These results suggest that it is possible that some of the clones evaluated can produce sexual seed, and that pollen viability is not a trait that can be easily selected against. Special attention must be given to sexual reproduction under tropical conditions in breeding and selection programs for energycane. This characteristic might represent a serious risk for commercial sugarcane plantations because the energycane could show a weedy behavior inside those plantations or become invasive and affect natural areas in the tropics that are rich in biodiversity.

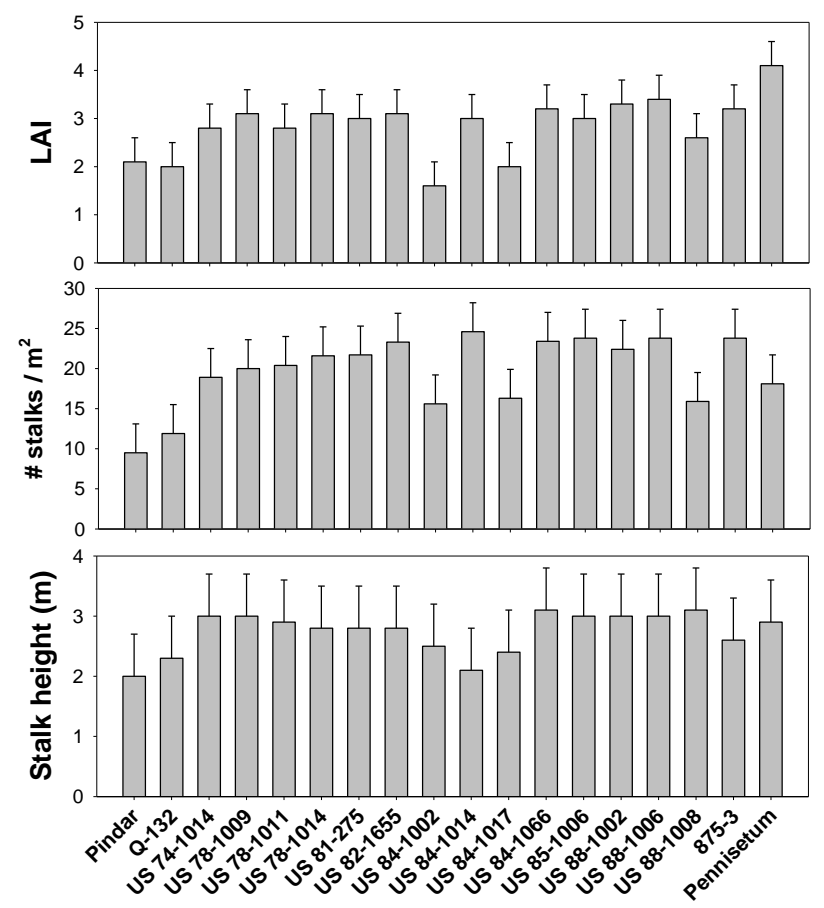

Figure 3. Leaf area index, stalk density and height for two sugarcane (Pindar and Q-132), fifteen energycane clones (US clones and 875-3) and Pennisetum purpureum, grown under tropical conditions in Limón, Costa Rica in 2010. The values are averages of monthly measurements during the first six months after planting. Error bars represent the least significant difference $(\alpha=0.05)$.

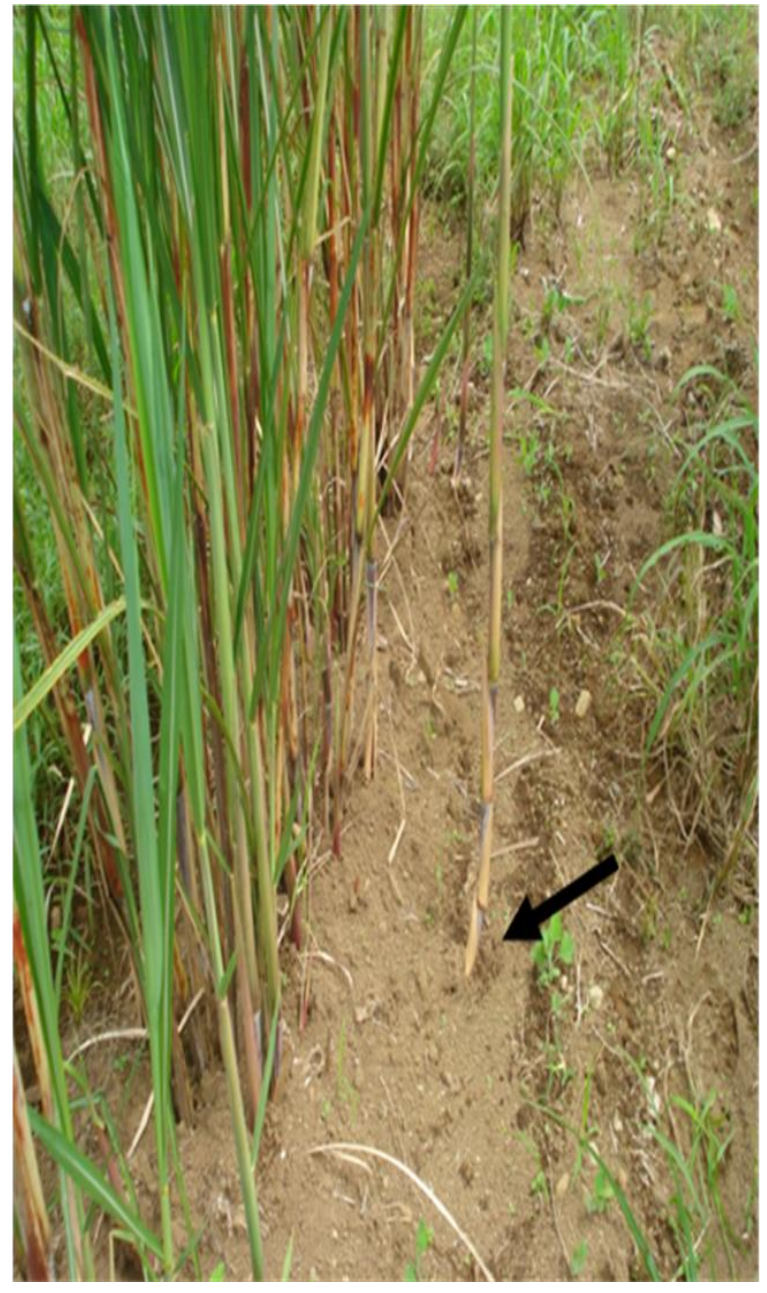

Figure 4. Lateral vegetative growth of energycane (indicated by the arrow) grown under tropical conditions in Limón, Costa Rica in 2010.

\section{Conclusions}

The information generated so far, clearly shows that energycane could become an important crop for biomass production. Burner et al. (2009) found that unlike other grass species energycane has a high capacity to accumulate most of their dry mass in their stems and leaves maintaining a ratio of 2:1 for these two structures. Thus, variables such as stalk number and leaf area index are good indicators of biomass production potential as observed in the present study and should be useful phenotypic selection markers. 
Other studies conducted in sub-tropical countries have reported that there are high genetic correlations in biomass related traits making possible to use information from selection trials conducted in one country to anticipate or predict the behavior of the germplasm in another country (Wang et al. 2008). However, the behavior of this germplasm varies importantly between tropical and sub-tropical conditions. Therefore, selection and breeding programs must be carefully developed accounting for the unique responses that the germplasm could show under these two different climatic conditions. It is particularly critical that besides crop growth and productivity parameters, invasiveness risk is evaluated under tropical conditions. In this regard, flowering is the most important trait that increases this risk. Selecting against flowering or generating sterile lines either through traditional breeding or transgenic approaches will reduce the ecological risk of energycane and facilitate its use in the tropics.

\section{Literature Cited}

Burner, D.M., T.L. Tew, J.J. Harvey and D.P. Belesky. 2009. Dry matter partitioning and quality of Miscanthus, Panicum, and Saccharum genotypes in Arkansas, USA. Biomass and Bioenergy 33:610-619.

Gomez, L.D., C.G. Steele-King and S.J. McQueen-Mason. 2008. Sustainable liquid biofuels from biomass: the writing's on the wall. New Phytologist 178:473-485.

Heaton, E., F.G. Dohleman and S.P. Long. 2008. Meeting US biofuel goals with less land: the potential of Miscanthus. Global Change Biology 147:2000-2014.

Hill, J., S. Polasky, E. Nelson, D. Tilman, H. Huo, L. Ludwig, J. Neumann, H. Zheng and D. Bonta. 2009. Climate change and health costs of air emissions from biofuels and gasoline. Proceedings of the National Academy of Sciences 106(6):2077-2082.
Long, S.P. 2008. Opportunities for enhancing the productivity of biofeedstocks and minimizing inputs: theory and practice. In A. Eaglesham, S.A. Slack, and R.W.F. Hardy (ed.) Reshaping American agriculture to meet its biofuel and polymer roles. National Agricultural Biotechnology Council 20:109-118.

Mack, R.N. 2008. Evaluating the credits and debits of a proposed biofuel species: Giant reed (Arundo donax). Weed Science 53:883-888.

Matineo, M., G.M. D’Agosta, V. Copani, C. Patane and S.L. Cosentino. 2009. Biomass yield and energy balance of three perennial crops for energy use in the semi-arid Mediterranean environment. Field Crops Research 114:204-213.

Morgan, K.T., R.A. Gilbert, Z.A. Helsel, L. Baucum, R. Leon and J. Perret. 2010. White paper report from working groups attending the international conference on research and educational opportunities in bio-fuel crop production. Biomass and Bioenergy 34:19681972.

Ohlrogge, J., D. Allen, B. Berguson, D. DellaPenna, Y. Shachar-Hill and S. Stynme. 2009. Driving on biomass. Science 324:1019-1020.

Tilman, D., R. Socolow, J.A. Foley, J. Hill, E. Larson, L. Lynd, S. Pacala, J. Reilly, T. Searchinger, C. Sommerville and R. Williams. 2009. Beneficial biofuels_-The food, energy, and environment trilemma. Science 325:270-271.

Wang, L.P., P.A. Jackson, X. Lu, Y.H. Fan, J.W. Foreman, X.K. Chen, H.H. Deng, C. Fu, L. Ma and K.S. Aitken. 2008. Evaluation of sugarcane $\times$ Saccharum spontaneum progeny for biomass composition and yield components. Crop Science 48:951-961.

Recibido para publicación el 21 de diciembre de 2010. Aceptado para publicación el 1 de febrero de 2011. 